\title{
Identification and Evaluation of Strain B37 of Bacillus subtilis Antagonistic to Sapstain Fungi on Poplar Wood
}

\author{
XiaoHua Zhang, ${ }^{1,2}$ GuiHua Zhao, ${ }^{2}$ DeWei Li, ${ }^{3}$ ShunPeng Li, ${ }^{1}$ and Qing Hong ${ }^{1}$ \\ ${ }^{1}$ Key Laboratory of Agricultural Environmental Microbiology, Ministry of Agriculture, College of Life Sciences, \\ Nanjing Agricultural University, Nanjing, Jiangsu 210095, China \\ ${ }^{2}$ Jiangsu Polytechnic College of Agriculture and Forestry, Jurong, Jiangsu 212400, China \\ ${ }^{3}$ The Connecticut Agricultural Experiment Station Valley Laboratory, 153 Cook Hill Road, Windsor, CT 06095, USA \\ Correspondence should be addressed to Qing Hong; doudou15335275925@126.com
}

Received 20 January 2014; Revised 4 August 2014; Accepted 8 August 2014; Published 21 October 2014

Academic Editor: Tadashi Takamizo

Copyright (C) 2014 XiaoHua Zhang et al. This is an open access article distributed under the Creative Commons Attribution License, which permits unrestricted use, distribution, and reproduction in any medium, provided the original work is properly cited.

Devaluation of poplar products by sapstain accounts for huge and unpredictable losses each year in China. We had isolated four poplar sapstain fungi, Ceratocystis adiposa Hz91, Lasiodiplodia theobromae YM0737, L. theobromae Fx46, and Fusarium sp. YM05, from five poplar varieties and 13 antagonistic bacteria from nine diverse varieties. After being experimented with agar plates, wood chips, and enzyme activities, strain B37 was identified as the best poplar sapstain biocontrol bacterium. The strain B37 was identified as Bacillus subtilis using sequences of the $16 \mathrm{~S}$ rRNA gene, physiological biochemical, and morphological characteristics.

\section{Introduction}

Hartig [1] confirmed that wood discoloration was caused by a dark mycelial fungus. It was the start of wood stain fungi research. Since then, a large number of studies on stain fungi had been carried out. The molds caused sapstain of pine, kumquat, grapevine, Abies balsamea (Linn.) Mill., Picea mariana (Mill.) B.S.P., and so forth include species of the genera Ceratocystis Ellis \& Halst, Ophiostoma piceae (Münch) Syd. \& P. Syd., Diplodia Fr., Lasiodiplodia Ellis \& Everhart, and so forth [2-4]. These molds caused a wide spectrum of sapwood discoloration including black, red, violet, orange, and green [5]. The predominant wood discoloring species belonged to Ascomycota, which included Lasiodiplodia, Ceratocystis, Diplodia, Alternaria Nees, and Cladosporium Link $[4,6]$.

Sapstain and mold growth on lumber were the serious problems in the wood process industry [7]. Biodiscoloration caused by molds in the initial stage of wood decay was one of the most serious discolorations. It caused serious damage to wood, which not only existed on the surface of the wood, but also penetrated wood into its deep interior $[8,9]$. Chapman and Scheffer [10] proved that blue stain fungi (Ceratostomella pilifera (Fr.) G. Winter, C. pini Münch, C. ips Rumbold, Graphium rigidum (Pers.) Sacc.) could discolor Pinus echinata Mill., P. ponderosa Dougl. ex Laws., and $P$. taeda $\mathrm{L}$. The toughness reduced from $9 \%$ to $75 \%$; specific gravity losses reached from $1.4 \%$ to $3.8 \%$, respectively. The discoloration was objectionable to buyers and highly detrimental to the pulp and paper industry.

In the USA, estimates suggested that about ten million dollars were spent on chemical control each year to prevent sapstain fungi from colonizing the sapwood of sawn lumber, such as methylene bisthiocyanate [11-14]. Behrendt [15] proved that treating the ends of freshly cut timber with the nonpigmented strain of Ophiostoma piliferum (Fr.) Syd. and P. Syd. and spraying logs with Dursban 4E could reduce growth of blue stain fungi Phanerochaete gigantea (Fr.) S. S. Rattan to $23 \%$ in red pine and Pinus resinosa Ait. Other chemicals, such as pentachlorophenol, methyl bromide, 3iodo-2-propynyl butyl carbamate, copper-8-quinolinolate, vinclozolin, iprodione, and procymidone, have been used as fungicides in pine, oak, and poplar [16-21].

Because toxic chemicals may cause secondary pollution in the environment and accumulation in animal tissues, many researchers used various biological methods to inhibit 


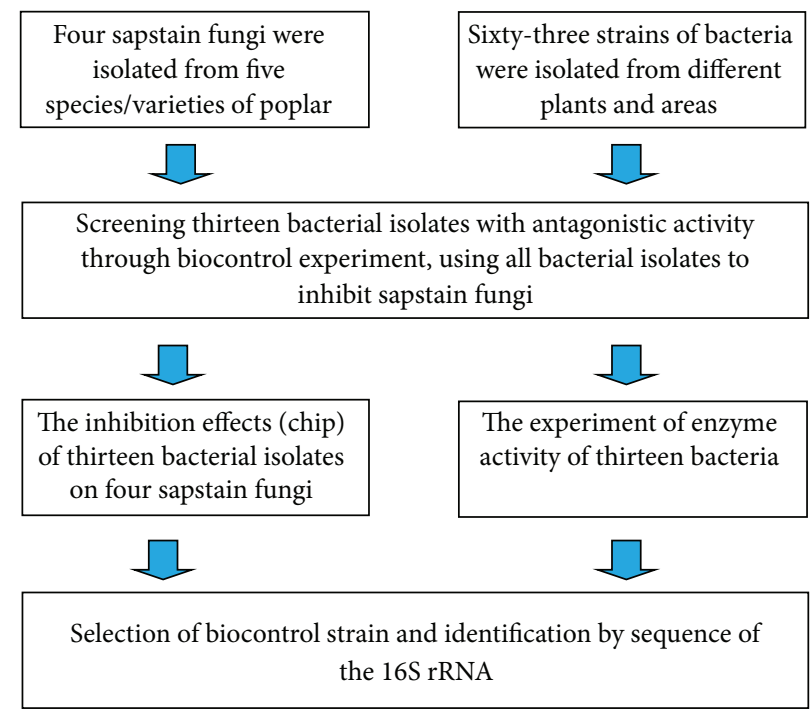

FIGURE 1: Selection method of biocontrol bacteria for poplar discoloration.

the growth of sapstain [22]. Biological control of sapstain fungi (Sphaeropsis sapinea (Fr.) Dyko \& B. Sutton (syn. Diplodia pinea (Desm.) J. Kickx f.), Ophiostoma minus, Ophiostoma floccosum Math.-Käärik, and O. ips (Rumbold) Nannf.) has been investigated in laboratory trials on wood blocks of Pinus sp. using several strains of fungi, such as Trichoderma sp., Trichothecium roseum (Pers.) Link and Phlebiopsis gigantea (Fr.) Jülich [23, 24]. Morin et al. [25] discovered that a spontaneous albino strain, Ceratocystis resinifera Kasper, has the ability to prevent discoloration of spruce sapwood caused by wild-type sapstain fungi. Some genera of bacteria (i.e., Bacillus, Pseudomonas, Lactobacillus, and Streptomyces) also have been investigated in laboratory experiments or field trails to control sapstain fungi [24, 26-32]. Forty-five fungal isolates were tested for the sensitivity to Bacillus subtilis C186. Only Phialophora richardsiae 616E appeared unaffected by the Bacillus [30]. The results showed that Bacillus subtilis C186 had a wide variety of inhibitory effects on sapstain fungi. However, the report about biocontrol of sapstain fungi in poplar is seldom.

The objectives of our study were to screen bacterial strains for their antagonistic activity against the discoloration of poplar wood and to compare the efficiency of different bacteria in preventing sapstain under the same conditions.

\section{Materials and Methods}

2.1. Materials. Discolored sapwood of four poplar hybrids was collected from Feixian City, Shandong Province, and Jurong, Siyang, and Suining Cities, Jiangsu Province, between April 2006 and October 2008. Four sapstain fungal strains, Ceratocystis adiposa (E. J. Butler) C. Moreau, Hz91 from Populus deltoides cv. "Zhonghe" and Populus $\times$ euramericana cv. "74/76" at Siyang city, Lasiodiplodia theobromae (Pat.) Griffon \& Maubl., YM0737 and FX46 from P. deltoides cl. "Zhonglin-46" and P. deldoides Bartr. cv. "Lux" (I-69/55) at Feixian and Suining cities, Fusarium lateritium Ness, YM05 from $P$. deltoides cv. "harvard" $\times P$. deltoides $\mathrm{cv}$. "Lux" $\mathrm{cv}$. "Nanlin351" at Jurong City, were isolated by the Center of Biotechnology in Jiangsu Polytechnic College of Agriculture and Forestry, Jiangsu Province, China.

\subsection{Methods}

2.2.1. Screening for Bacteria for Biocontrol against Poplar Discoloration Fungi. The method used to select and identify bacteria for biocontrol against poplar discoloration fungi was shown in Figure 1.

2.2.2. Isolation of Biocontrol Bacteria. Healthy and diseased timber, twigs and leaves of Populus $\times$ euramericana (Dode) Guineir cv. "San Martino" (I-72/58), Populus $\times$ euramericana CL “74/76," Populus deltoides cv. "Zhonghe," Camellia oleifera Abel, Magnolia grandiflora Linn, Phoebe neurantha Gamble, Pinus thunbergii Parl., Photinia $\times$ fraseri, were collected from Linyi and Heze Cities, Shandong Province, and Jurong, Siyang, and Shuyang Cities, Jiangsu Province, between February 2009 and December 2010. The materials washed with $70 \%$ alcohol for five minutes were cut into blocks $(3 \times 3 \times 3 \mathrm{~mm})$. Every sample was divided into $40-60$ blocks which were transferred to Petri dishes with Luria-Bertani (LB) medium (tryptone, $10 \mathrm{~g}$; yeast extract, $5 \mathrm{~g} ; \mathrm{NaCl}, 10 \mathrm{~g}$; add deionized $\mathrm{H}_{2} \mathrm{O}$ to $950 \mathrm{~mL}$; adjust the $\mathrm{pH}$ to 7.0 with $5 \mathrm{~N} \mathrm{NaOH}$. Adjust the volume to 1 liter with deionized $\mathrm{H}_{2} \mathrm{O}$. It was prepared with $15 \mathrm{~g} \mathrm{~L}^{-1}$ agar. Medium was sterilized at $121^{\circ} \mathrm{C}$ for $30 \mathrm{~min}$ ). The plates were incubated for 7 days in dark at $28 \pm 1^{\circ} \mathrm{C}$ and RH 70\% in a PRC-250A intelligent artificial climate incubator (Zhejiang, China).

2.2.3. Screening for Antifungal In Vitro Activity. The method of screening for antifungal in vitro activity was shown in Figure 2. Four species of sapstain fungi were cultivated with PDA plates for 5 days at $28 \pm 1^{\circ} \mathrm{C}$ and cut into $0.8-\mathrm{cm}$ diameter plugs using a cork borer, respectively. Each plug was 


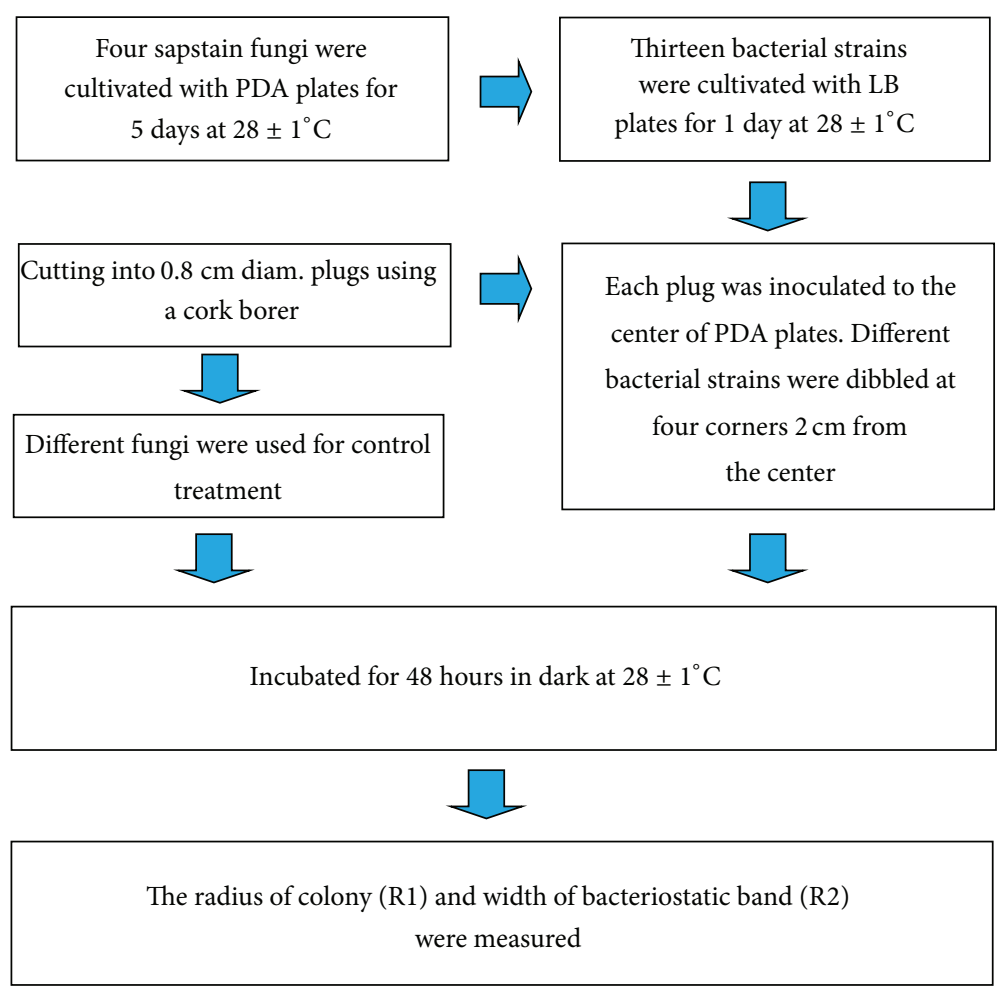

FIGURE 2: Method of screening for antifungal in vitro activity.

inoculated to the center of PDA plates. Different bacterial strains were dibbled at four corners 2 centimeters from the center. All treatments were conducted in quintuplicate. Different fungi (Hz91, YM05, YM0737, and Fx46) were used for control treatment. The cultures were incubated for 48 hours in dark at $28 \pm 1^{\circ} \mathrm{C}$ and $\mathrm{RH} 70 \%$ in a PRC-250A intelligent artificial climate incubator. The radius of colony (R1) and width of bacteriostatic band (R2) were measured. The ratio of $\mathrm{R} 2$ to $\mathrm{R} 1$ represented bacteriostatic intensity.

2.2.4. Biocontrol Experiment of Chip. Thin chips $(5 \times 2 \times$ $0.6 \mathrm{~cm}$ in size) of Populus $\times$ euramericana (Dode) Guineir cv. "San Martino" (I-72/58) were sterilized for $30 \mathrm{~min}$ at $121^{\circ} \mathrm{C}$. LB liquid cultures of 13 bacteria were cultured for 60 hours at $120 \mathrm{rpm} / \mathrm{min}$ and $28 \pm 1^{\circ} \mathrm{C}$. The chips were dipped in bacterial cultures for $1 \mathrm{~min}$, removed, and then air dried. The chip for control experiment was dipped in LB liquid medium for $1 \mathrm{~min}$. Plugs of $0.8 \mathrm{~cm}$ diameter of four species of sapstain fungi that were grown on PDA plates for 5 days were used to inoculate the center of chips, respectively. Sterilized chips were put on a piece of filter paper over vermiculite in Petri dishes. The treated chips were cultivated separately for 4,8 , and 12 days at $28 \pm 1^{\circ} \mathrm{C}$ for observing results.

2.2.5. Screening for Enzyme Activity. Thirteen bacteria were inoculated on casein, chitin, or beta-glucan extract agar in Petri dishes according to the method of Cota et al. [33]. All treatments were conducted in quintuplicate and all plates were incubated at $28 \pm 1^{\circ} \mathrm{C}$. The color change of the medium was observed after 2 days. The width of color change band represents protease, chitinase, and beta-glucanase activity.

\subsubsection{Detailed Identification for Candidate of the Biocontrol} Agents. For identification for candidates of the biocontrol agents, the methods of morphological, physiological, and biochemical characteristics as well as molecular biological technology were used. The detailed procedure and methods of physiological and biochemical tests of the candidate were according to the Manual of Systematic and Determinative Bacteriology [34] and Bergey's Manual of Determinative Bacteriology, 9th edition [35]. Gram-stain of the candidate was observed under an optical compound microscope ZEISS Imager A1 (Carl Zeiss, Jena, Germany) $(n=30)$. The morphology of cells was examined by transmission electron microscopy (Hitachi, Tokyo, Japan). Bacterial cells cultured for 10 hours for electron microscopy were picked up using an inoculating loop and dipped in a drop of water to make suspension. The suspension was transferred to carbon-coated copper grids with a capillary pipet. After a short time, excess liquid was absorbed with a piece of filter paper from the edge of the copper grids. Cells were negatively stained with $2 \%$ phosphotungstic acid for 90 seconds. A piece of filter paper was used to absorb extra dye. The sample was air dried and examined.

2.2.7. PCR Amplification and Sequencing of 16s rRNA. Total DNA was extracted and purified according to the procedure described by Devereux and Willis [36]. Agarose 
TABLE 1: The isolation of biocontrol bacteria from different plants.

\begin{tabular}{|c|c|c|c|c|c|c|}
\hline Trial & Plants & $\begin{array}{l}\text { Isolation } \\
\text { localities }\end{array}$ & $\begin{array}{l}\text { Total number of } \\
\text { samples }\end{array}$ & $\begin{array}{l}\text { Number of } \\
\text { isolates tested }\end{array}$ & $\begin{array}{l}\text { Antagonistic } \\
\text { number }\end{array}$ & $\begin{array}{l}\text { Selected for } \\
\text { further } \\
\text { investigations }\end{array}$ \\
\hline 1 & $\begin{array}{l}\text { Populus } \times \text { euramericana } \\
\text { (Dode) Guineir cv. "San } \\
\text { Martino" (I-72/58) }\end{array}$ & $\begin{array}{c}\text { Wood } \\
\text { discoloration, } \\
\text { bark, bud }\end{array}$ & 56 & 12 & 3 & 3 \\
\hline 2 & $\begin{array}{c}\text { Populus } \times \text { euramericana } \\
\text { CL "74/76" }\end{array}$ & $\begin{array}{l}\text { Normal branch } \\
\text { for } 1 \text { year, canker }\end{array}$ & 42 & 8 & 3 & 1 \\
\hline 3 & $\begin{array}{c}\text { Populus deltoides cv. } \\
\text { "Zhonghe" }\end{array}$ & canker & 47 & 9 & 3 & 2 \\
\hline 4 & Camellia oleifera Abel & Leaf spot & 45 & 6 & 2 & 2 \\
\hline 5 & Magnolia grandiflora Linn & Leaf spot & 50 & 10 & 4 & 2 \\
\hline 6 & Phoebe neurantha Gamble & Leaf spot & 50 & 5 & 1 & 1 \\
\hline 7 & Pinus thunbergii Parl. & Normal leaf & 45 & 4 & 1 & 1 \\
\hline 8 & $\begin{array}{c}\text { Photinia } \times \text { fraseri red } \\
\text { robin }\end{array}$ & $\begin{array}{c}\text { Branch scab and } \\
\text { leaf spot }\end{array}$ & 60 & 9 & 2 & 1 \\
\hline \multicolumn{3}{|c|}{ Total } & 395 & 63 & 19 & 13 \\
\hline
\end{tabular}

(0.7\%) gel electrophoresis was used to verify DNA quality. The following universal primers were used to amplify the nearly complete $16 \mathrm{~s}$ rRNA. The forward primer was $5^{\prime}-$ AGAGTTTGATCCTGGCTCAG-3', and the reverse primer was $5^{\prime}$-GCCTTGTACACACCGCCC-3' [37]. The total volume $(25 \mu \mathrm{L})$ of the PCR reaction mixture contained $2.5 \mu \mathrm{L}$ of $10 \times$ Taq buffer, $1.5 \mu \mathrm{L}$ of $\mathrm{MgCl}_{2}\left(25 \mathrm{mmol} \mathrm{L}^{-1}\right), 2 \mu \mathrm{L}$ of each deoxyribonucleoside triphosphate $\left(10 \mathrm{mmol} \mathrm{L}^{-1}\right), 1 \mu \mathrm{L}$ of each primer $(30 \mathrm{pmol}), 1 \mu \mathrm{L}$ of DNA template, $0.5 \mu \mathrm{L}$ of Taq DNA polymerase, and $15.5 \mu \mathrm{L}$ of $\mathrm{H}_{2} \mathrm{O}$. The PCR reaction was performed using a GeneAmp PCR System 9700 (Applied Biosystems, Shanghai, China) with the following thermal program: an initial denaturation step $\left(94^{\circ} \mathrm{C}, 5 \mathrm{~min}\right)$ followed by 30 cycles of denaturation $\left(95^{\circ} \mathrm{C}, 30 \mathrm{~s}\right)$, annealing $\left(54^{\circ} \mathrm{C}\right.$, $30 \mathrm{~s})$, and extension $\left(72^{\circ} \mathrm{C}, 60 \mathrm{~s}\right)$. After a final extension step $\left(72^{\circ} \mathrm{C}, 20 \mathrm{~min}\right)$, samples were kept at $4^{\circ} \mathrm{C}$. The GenScript Co., Ltd. (Nanjing, China) sequenced the $16 \mathrm{~s}$ rRNA gene. The $16 \mathrm{~S}$ rRNA of the thirteen bacteria was aligned with published sequences from the GenBank database using Bioedit 7.0 alignment tool comparison software.

2.3. Data Analysis. Statistical analysis of the results was performed using the SPSS13.0 analytical software.

\section{Results and Analysis}

3.1. Selection of Biocontrol Bacteria. Sixty-three strains of bacteria (Bacillus, Pseudomonas, Enterobacter, and Streptomyces) were isolated from different plants, but 19 strains showed antagonistic activity to four poplar discoloration fungi (Table 1). Thirteen strains were selected for further investigation. Table 2 showed that Bacillus and Pseudomonas were the predominant genus, and Bacillus subtilis and Bacillus amyloliquefaciens were the dominant species in 13 strains. The results were similar to the study of Seifert et al. [30].

3.2. Experiment of Biocontrol. The antagonistic activity of 13 bacteria to 4 species of poplar sapstain fungi was showed in Table 3. The results showed that strains B82 and B37 had strongest inhibition of Hz91, YM05, YM0737, and FX46. The inhibition of strains B4 and B1 to four fungi was the worst. Strain B9 antagonizes only YM05. Strain B123 had inhibitory effect on the fungus Hz91. The ratio of R2 to R1 of strain B82 to Hz91 and YM05 is 1.35 and 1.89, respectively. The ratio of R2 to R1 of strain B37 to YM0737 is 1.33. Antagonistic activity of strains B82 and B37 to FX46 is similar; the ratio of R2 to R1 is 1.41 and 1.40 , respectively. Statistical analysis of these results showed no significant difference $(P<0.05)$ for Hz91, YM05, and FX46 between strain B82 and strain B37. Significant difference $(P<0.05)$ between strain B82 and strain B37 was for YM0737.

The results of the chip experiment were showed in Table 3. The strains of B4, B9, B33, B123, and B1 had no antagonistic effect on the 4 species of poplar sapstain fungi. The strains of B37 and B82 expressed antagonistic effect. FX46, YM05, and Hz91 were inhibited for 12 days by B37, whereas YM0737 was inhibited only for 8 days. The strain of B82 had antagonistic effect on FX46 and YM05 for 12 days, but on Hz91 for 8 days and on YM0737 for 4 days.

The enzymes activity of 13 bacteria was showed in Table 3. The results showed that all 13 bacteria did not produce chitinase. Strain B37 was the best bacterium to produce $\beta$ glucanase; the width of color change band is $4.25 \mathrm{~cm}$. There was only a little amount of $\beta$-glucanase produced by strains $\mathrm{B} 33$ and B13; the width of color change band is $0.29 \mathrm{~cm}$ and $0.38 \mathrm{~cm}$, respectively. Strains B82, B8, and B9 showed a better activity to produce protease than those of strains of B47, B27, $\mathrm{B} 4, \mathrm{~B} 30$, and B37. The width of color change band is $4.13 \mathrm{~cm}$ by strain B82. Other bacteria did not produce protease. Analysis of enzymes activity showed a significant difference $(P<0.05)$ between strain B82 and strain B37.

In experiment of antifungal in vitro activity, thirteen strains were proved to inhibit 4 sapstain fungi. Nine strains (B8, B13, B27, B33, B37, B47, B82, B123, and B140) of them are Bacillus. Three strains (B4, B9, and B30) of them belong to Pseudomonas. One (B1) is Streptomyces. The ratio of R2 to 
TABLE 2: The source of 13 biocontrol bacteria.

\begin{tabular}{|c|c|c|c|}
\hline Strain & Identification & Sample source & Sampling localities \\
\hline B1 & Streptomyces setonii & $\begin{array}{l}\text { Leaf spot of Camellia } \\
\text { oleifera Abel }\end{array}$ & $\begin{array}{l}\text { Jurong, Jiangsu } \\
\text { Province, China }\end{array}$ \\
\hline B4 & $\begin{array}{l}\text { Pseudomonas } \\
\text { fluorescens }\end{array}$ & $\begin{array}{l}\text { Leaf spot of Magnolia } \\
\text { grandiflora Linn }\end{array}$ & $\begin{array}{l}\text { Jurong, Jiangsu } \\
\text { Province, China }\end{array}$ \\
\hline B8 & $\begin{array}{l}\text { Bacillus } \\
\text { amyloliquefaciens }\end{array}$ & $\begin{array}{l}\text { Leaf spot of Magnolia } \\
\text { grandiflora Linn }\end{array}$ & $\begin{array}{l}\text { Jurong, Jiangsu } \\
\text { Province, China }\end{array}$ \\
\hline B9 & $\begin{array}{l}\text { Pseudomonas } \\
\text { fluorescens }\end{array}$ & $\begin{array}{l}\text { Leaf spot of Phoebe } \\
\text { neurantha Gamble }\end{array}$ & $\begin{array}{l}\text { Jurong, Jiangsu } \\
\text { Province, China }\end{array}$ \\
\hline B13 & $\begin{array}{l}\text { Bacillus } \\
\text { stratosphericus }\end{array}$ & $\begin{array}{l}\text { Ulcer of Populus deltoides } \\
\text { cv. "Zhonghe" }\end{array}$ & $\begin{array}{l}\text { Jinan, Shandong } \\
\text { Province, China }\end{array}$ \\
\hline B27 & Bacillus subtilis & $\begin{array}{l}\text { Bark and wood of Populus } \\
\times \text { euramericana (Dode) } \\
\text { Guineir cv. "San Martino" } \\
\text { (I-72/58)I-72 }\end{array}$ & $\begin{array}{l}\text { Siyang and Suining, } \\
\text { Jiangsu Province, China }\end{array}$ \\
\hline B30 & $\begin{array}{l}\text { Pseudomonas } \\
\text { fluorescens }\end{array}$ & $\begin{array}{l}\text { Bud and wood of Populus } \times \\
\text { euramericana (Dode) } \\
\text { Guineir cv. "San Martino" } \\
\text { (I-72/58)I-72 }\end{array}$ & $\begin{array}{l}\text { Shuyang, Jiangsu } \\
\text { Province, China }\end{array}$ \\
\hline B33 & $\begin{array}{l}\text { Bacillus } \\
\text { methylotrophicus }\end{array}$ & $\begin{array}{l}\text { Brown patch of Populus } \times \\
\text { euramericana (Dode) } \\
\text { Guineir cv. "San Martino" } \\
\text { (I-72/58)I-72 }\end{array}$ & $\begin{array}{l}\text { Siyang, Jiangsu Province, } \\
\text { China }\end{array}$ \\
\hline B37 & Bacillus subtilis & $\begin{array}{l}\text { Normal leaf of Pinus } \\
\text { thunbergii Parl. }\end{array}$ & $\begin{array}{l}\text { Jurong, Jiangsu } \\
\text { Province, China }\end{array}$ \\
\hline B47 & Bacillus subtilis & $\begin{array}{l}\text { Canker and wood of } \\
\text { Populus } \times \text { euramericana CL } \\
\text { “74/76"I-107 }\end{array}$ & $\begin{array}{l}\text { Mengyin, Feixian, } \\
\text { Yinan, Yiyuan, Junan, } \\
\text { Luozhuang, Lanshan, } \\
\text { Shandong Province, } \\
\text { China }\end{array}$ \\
\hline B82 & $\begin{array}{l}\text { Bacillus } \\
\text { amyloliquefaciens }\end{array}$ & $\begin{array}{l}\text { Leaf spot of Photinia } \times \\
\text { fraseri red robin }\end{array}$ & $\begin{array}{l}\text { Jurong, Jiangsu } \\
\text { Province, China }\end{array}$ \\
\hline B123 & Bacillus subtilis & $\begin{array}{l}\text { Canker of Populus deltoides } \\
\text { cv. "Zhonghe" }\end{array}$ & $\begin{array}{l}\text { Feixian, Shandong } \\
\text { Province, China }\end{array}$ \\
\hline B140 & $\begin{array}{l}\text { Bacillus } \\
\text { amyloliquefaciens }\end{array}$ & $\begin{array}{l}\text { Leaf spot of Camellia } \\
\text { oleifera Abel. }\end{array}$ & $\begin{array}{l}\text { Jurong, Jiangsu } \\
\text { Province, China }\end{array}$ \\
\hline
\end{tabular}

R1 of strain B82 to Hz91, YM05, YM0737, and FX46 is 1.35, $1.89,1.00$, and 1.41 , respectively. The ratio of $\mathrm{R} 2$ to $\mathrm{R} 1$ of strain B37 to Hz91, YM05, YM0737, and FX46 is 0.99, 1.48, 1.33, and 1.40, respectively. In experiment of chip, YM05 and FX46 were biocontrolled by B37 and B82 for 12 days. However, strain of B37 can inhibit Hz91 and YM0737 for 12 and 8 days, respectively. Strain of B82 can inhibit Hz91 and YM0737 for 8 and 4 days, respectively. So strain B37 of Bacillus subtilis was a better biocontrol bacterium than B82 on poplar sapstain ( $C$. adiposa Hz91, L. theobromae YM0737, L. theobromae Fx46, and Fusarium sp., YM05).

3.3. Morphological Characteristics of Strain B37. Strain B37 was Gram-positive rod-shaped with blunt ends (Figure 3(a)). On LB medium, colony was larger, milky white, of $3 \sim 5 \mathrm{~mm}$ diameter, after training 24 hours, with the raised surface being dry and wrinkled. The size was $1.83 \sim 2.41 \times 0.56-1.02 \mu \mathrm{m}$, with an average of $2.1 \times 0.74 \mu \mathrm{m}$ with peritrichous flagella (Figure 3(b)). Endospore was located in the middle of the cell and the size was $0.62 \sim 1.08 \times 0.44 \sim 0.66 \mu \mathrm{m}$ with an average of $0.86 \times 0.51 \mu \mathrm{m}$.

3.4. Physiological and Biochemical Characteristics of Strain B37. According to the Manual of Systematic and Determinative Bacteriology [34] and Bergey's Manual of Determinative Bacteriology, 9th edition [35], results of tests on physiological and biochemical characteristics of strain B37 identified strain B37 as Bacillus subtilis (Ehreberg) Cohn (Table 4). The results showed that treatment of indole reaction, gas production, and lactose have no effect, and the other 18 treatments have positive effect.

3.5. The 16S rRNA of Strain B37 Sequencing and Phylogenetic Tree. The results of the $16 \mathrm{~S}$ rRNA of strain B37 sequencing and aligning with published sequences from the GenBank database demonstrated that strain B37 had a 99.3\% similarity to Bacillus subtilis NCIB $3610^{\mathrm{T}}$ (GenBank accession number ABQL01000001) (CP000560) (Figure 4). According to morphology, physiological and biochemical characteristics, 


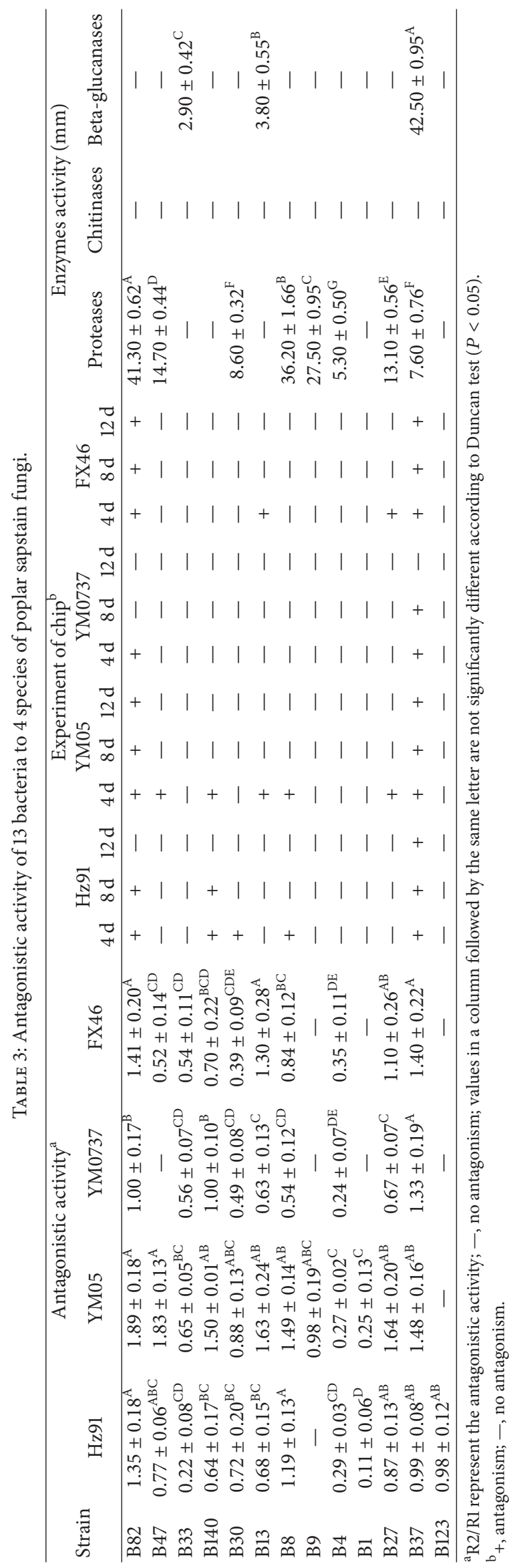




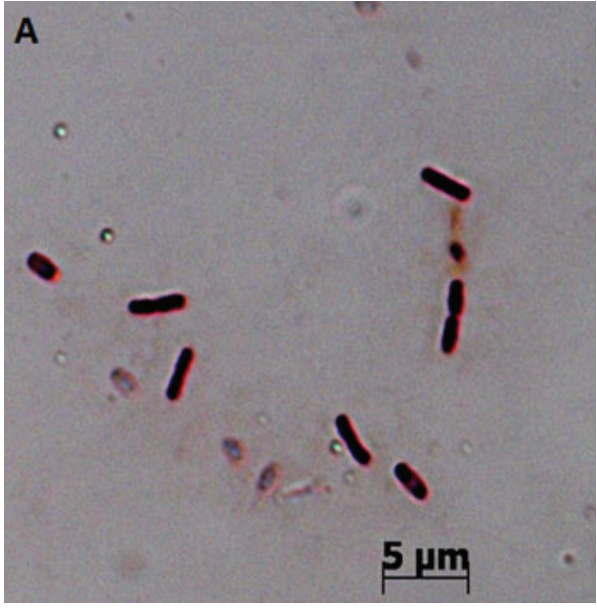

(a)

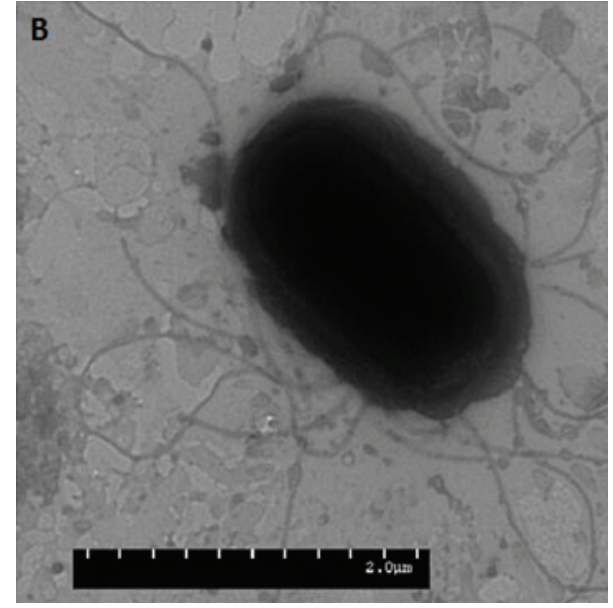

(b)

FIgURE 3: Morphology of Bacillus subtilis strain B37. (a) Rod-shaped cells of strain B37. (b) Flagella on a bacterial cell of strain B37 (the photo was taken with TEM at the Life Science Laboratory Center of Nanjing Agriculture University, China).

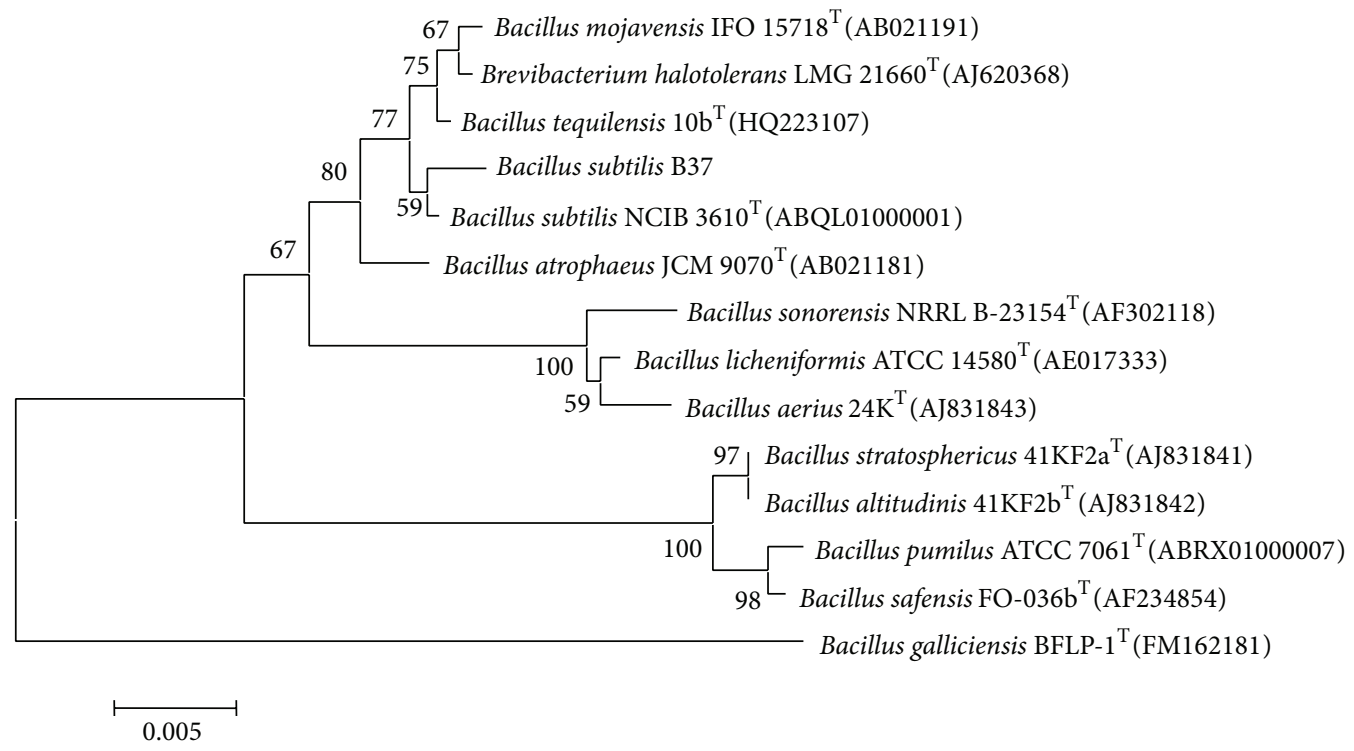

FIGURE 4: A neighbor-joining phylogenetic dendrogram based on 16S rRNA gene sequences showing the position of strain B37 among members of the genus Bacillus species. Numbers on branch nodes are percentage bootstrap values (100 resamplings). The "T" in the figure means "type strain."

and 16S rRNA sequence, strain B37 was identified as Bacillus subtilis and 16S rRNA of strain B37 was deposited at GenBank under accession number JN656409. Strain B37 was storing at China General Microbiological Culture Collection Center (CGMCC number 4277).

\section{Discussion}

Sapstain fungi are economically important and have been studied for many years in different countries. The major sapstaining groups belong to the Aureobasidium, Ceratocystis, Ophiostoma, Sporothrix, Graphium, or Hyalorhynocladiella and Leptographium genera $[4,38]$.
In our work, we used four sapstain fungi (C. adiposa $\mathrm{Hz} 91$, L. theobromae YM0737 and FX46, and F. lateritium YM05) isolated from discolored poplar as pathogen. Lasiodiplodia theobromae which can cause death of the kumquat (Fortunella margarita (Lour.) Swingle) tree was isolated from tissue taken from the margin of discolored kumquat bark and wood on symptomatic branches in orchards in Taiwan [2]. Various studies confirmed that $L$. theobromae was the causal agents of dieback and canker of grapevines in northern Mexico and Pinus caribaea var. hondurensis and Citrus aurantifolia in Venezuela [3,39]. It also caused discoloration of rubberwood and heveawood in tropical countries [40, 41]. The ascomycete Ceratocystis resinifera is a pathogen of Picea and Pinus tree 
TABLE 4: Physiological and biochemical characteristics of strain B37.

\begin{tabular}{lc}
\hline Treatment & Results \\
\hline Oxidase & + \\
Catalase & + \\
Starch hydrolysis & + \\
Nitrate reduction & + \\
Gelatin liquefaction & + \\
V-p & + \\
Indole reaction & - \\
Glucose & \\
Acid production & + \\
Gas production & - \\
Lactose & - \\
Methyl red & + \\
Citric acid & + \\
Pectin & + \\
Sucrose & + \\
Maltose & + \\
Xylose & + \\
Galactose & + \\
Mannose & + \\
Fructose & + \\
Urease & + \\
\hline & +
\end{tabular}

+ , positive effect; -, no effect.

or freshly felled spruce and pine logs in Continental Europe, North America, Norway, and Canada [4, 42, 43]. Ceratocystis coerulescens (Münch) B. K. Bakshi can stain Jack pine, white spruce, lodgepole pine, and Corsican pine in Canada [44]. Fusarium spp. is one kind of Sapstain fungi from Pinus radiata D. Don in Korea [45]. However, the study on stain to poplar was scarce.

Strain B37 of Bacillus subtilis was the best biocontrol bacterium on poplar sapstain (C. adiposa Hz91, L. theobromae YM0737, L. theobromae Fx46, and Fusarium sp., YM05) of the 13 bacteria in our work. It was isolated from normal leaf of Pinus thunbergii. These observations agree with Feio et al. [46], who reported that the growth of Fusarium oxysporum was inhibited by $B$. subtilis 335 on yeast extract glucose broth (YGB) medium on days 11 and 14. Growth of F. oxysporum was significantly inhibited by $50 \%$ solution of YGB inoculated with 11-day-old B. subtilis 335 culture in blocks of maritime pine (Pinus pinaster). The 12 -h yeast malt (YM) broth medium of $B$. subtilis C186 can prevent the growth of several fungi, isolated from Pinus spp., Aureobasidium sp., Ceratocystis sp., Cytospora pini Desm., Ophiostoma sp., Penicillium sp., and Trichocladium sp. [30]. However, very few studies were biocontrol poplar sapstain by $B$. subtilis.

Chitinase and $\beta$-1,3-glucanase that degrade the fungal cell wall components, chitin and $\beta$-1,3-glucan, are important enzymes to control fungi (Fusarium solani (Mart.) Sacc., Neurospora crassa Shear \& B. O. Dodge, Rhizoctonia solani J. G. Kühn, Sclerotium rolfsii Sacc., and Pythium ultimum Trow) $[47,48]$. Cultivated for 2 days, strain B37 produced a significant amount of $\beta$-1,3-glucanase (the width of color change band is $4.25 \mathrm{~cm}$ ), effectively inhibiting the growth of four poplar sapstain fungi. It can produce a small amount of proteases (the width of color change band is $0.76 \mathrm{~cm}$ ), but chitinase was not found. $\beta-1,3$-Glucanase can catalyze the hydrolysis of $\beta$-1,3-dextran polymers, which inhibit the growth and reproduction of fungi [49]. $\beta$-1,3-Glucanase genes clearly resulted in resistance to infection by Fusarium [50]. Therefore, $\beta$-1,3-glucanase is one of the important inhibitions of the plant fungal disease, so the metabolic mechanism of strain B37 will be the direction of our further study.

\section{Conflict of Interests}

The authors declare that there is no conflict of interests regarding the publication of this paper.

\section{Acknowledgments}

This study was financially supported by grants from the Natural Science Foundation of Jiangsu Province, China (no. BK2008243) and the 948 Project of State Forestry Administration, China (no. 2006-4-79). The authors want to thank Bei Wang (Jiangsu Polytechnic College of Agriculture and Forestry) for her critical reading of the paper.

\section{References}

[1] R. Hartig, Die Zersetzungsercheinungen des Holzes der Nadelholzbaume under Eiche in forstlicher, botainischer, und chemischer Richtung, Springer, Berlin, Germany, 1878.

[2] W. H. Ko, I. T. Wang, and P. J. Ann, "Lasiodiplodia theobromae as a causal agent of kumquat dieback in Taiwan," Plant Disease, vol. 88, no. 12, pp. 1383-1383, 2004.

[3] J. R. Úrbez-Torres, G. M. Leavitt, J. C. Guerrero, J. Guevara, and W. D. Gubler, "Identification and pathogenicity of Lasiodiplodia theobromae and Diplodia seriata, the causal agents of bot canker disease of grapevines in Mexico," Plant Disease, vol. 92, no. 4, pp. 519-529, 2008.

[4] A. Uzunovic, D.-Q. Yang, P. Gagné et al., "Fungi that cause sapstain in Canadian softwoods," Canadian Journal of Microbiology, vol. 45, no. 11, pp. 914-922, 1999.

[5] R. A. Zabel and J. J. Morrell, Wood Microbiology: Decay and Its Prevention, Academic Press, San Diego, Calif, USA, 1992.

[6] D.-Q. Yang, "Isolation of wood-inhabiting fungi from Canadian hardwood logs," Canadian Journal of Microbiology, vol. 51, no. 1, pp. 1-6, 2005.

[7] J. W. Dubois, A. Byrne, and J. E. Clark, "Canadian bluestain fungi: variation in tolerance to sapstain control biocides," Forest Products Journal, vol. 50, no. 1, pp. 60-66, 2000.

[8] B. Kreber and A. Byrne, "Discolorations of hem-fir wood: a review of the mechanisms," Forest Products Journal, vol. 44, no. 5, pp. 35-42, 1994.

[9] J. C. Ward and W. Y. Pong, Wetwood in Trees: A Timber Resource Problem, USFS, 1980.

[10] A. D. Chapman and T. C. Scheffer, "Effect of blue stain on specific gravity and strength of southern pine," Journal of Agricultural Research, vol. 61, pp. 125-133, 1940. 
[11] J. A. Butcher, Laboratory Screening Trials for New Prophylactic Chemicals against Sapstain and Decay in Sawn Timber, New Zealand Forest Service, 1973.

[12] D. Eden, M. Hedley, B. Kreber, and R. N. Wakeling, "Protection of logs and lumber from fungal degrade," What S New in Forest Research. No. 244. FRI, Rotorua, New Zealand, 1997.

[13] T. Singh, B. Kreber, R. Wakeling, A. Stewart, and M. Jaspers, "Effect of methylene bisthiocyanate on propugales and established mycelium of two sapstain fungi," Forest Products Journal, vol. 56, no. 1, pp. 40-45, 2006.

[14] R. S. Smith, A. Byrne, and A. J. Cserjesi, New Fungicidal Formulations Protect Canadian Lumber, Western Laboratory, Forintek Canada Corporation, 1985.

[15] C. J. Behrendt, R. A. Blanchette, and R. L. Farrell, "An integrated approach, using biological and chemical control, to prevent blue stain in pine logs," Canadian Journal of Botany, vol. 73, no. 4, pp. 613-619, 1995.

[16] D. L. Cassens and W. E. Eslyn, "Field trials of chemicals to control sapstain and mold on yellow-poplar and southern yellow pine lumber," Forest Products Journal, vol. 33, no. 10, pp. 52-56, 1983.

[17] D. P. Cirelli, "Patterns of pentachlorophenol usage in the United States of America-an overview," in Pentachlorophenol, vol. 12 of Environmental Science Research, pp. 13-18, Springer, New York, NY, USA, 1978.

[18] K. R. Rao, Pentachlorophenol; Chemistry, Pharmacology, and Environmental Toxicology, Plenum Press, New York, NY, USA, 1978.

[19] S. G. Georgopoulos, M. Sams, and B. N. Ziogas, "Mitotic instability in Aspergillus nidulans caused by the fungicides iprodione, procymidone and vinclozolin," Pesticide Science, vol. 10, pp. 389-392, 1979.

[20] I. E. Tarocinski and M. H. Zieliński, Protection of Pine Sawtimber and Sawn Timber against Blue Stain in Poland, IRG Secretariat, 1982.

[21] K. M. Tubajika, J. J. Jonawiak, R. Mack, and K. Hoover, "Efficacy of radio frequency treatment and its potential for control of sapstain and wood decay fungi on red oak, poplar, and southern yellow pine wood species," Journal of Wood Science, vol. 53, no. 3, pp. 258-263, 2007.

[22] C. Leifert, H. Li, S. Chidburee et al., "Antibiotic production and biocontrol activity by Bacillus subtilis CL27 and Bacillus pumilus CL45," Journal of Applied Bacteriology, vol. 78, no. 2, pp. 97-108, 1995.

[23] G. Cornelia, B. Tsilla, S. Daniel, T. Thomas, M. Kurt, and F. Karin, "Biological control of Sapstain Fungi: from laboratory experiments to field trials 10th EWLP, Stockholm, Sweden, August 25-28, 2008," Holzforschung, vol. 63, no. 6, pp. 751-759, 2009.

[24] J. L. Vanneste, R. A. Hill, S. J. Kay, R. L. Farrell, and P. T. Holland, "Biological control of sapstain fungi with natural products and biological control agents: a review of the work carried out in New Zealand," Mycological Research, vol. 106, no. 2, pp. 228-232, 2002.

[25] C. Morin, P. Tanguay, C. Breuil, D.-Q. Yang, and L. Bernier, "Bioprotection of spruce logs against sapstain using an albino strain of Ceratocystis resinifera," Phytopathology, vol. 96, no. 5, pp. 526-533, 2006.

[26] R. Benko, "Biological control of blue stain on wood with Pseudomonas cepacia 6253: laboratory and field test," International Research Group on Wood Preservation Document No. IRGIWPI. 1380, 1989.
[27] S. C. Croan and T. L. Highley, "Biological control of sapwoodinhabiting fungi by living bacterial cells of Streptomyces yiosus as a bioprotetant," International Research Group on Wood Preservation Document IPG/WP/1564-1592, IRG, Stockholm, Sweden, 1992.

[28] M. Z. El-Fouly, A. A.-F. M. Shahin, and H. A.-A. El-Bialy, "Biological control of sapstain fungi in Egyptian wood stores and infected trees," Annals of Microbiology, vol. 61, no. 4, pp. 789-799, 2011.

[29] C. Moita, S. S. Feio, L. Nunes, M. J. M. Curto, and J. C. Roseiro, "Optimisation of physical factors on the production of active metabolites by Bacillus subtilis 355 against wood surface contaminant fungi," International Biodeterioration and Biodegradation, vol. 55, no. 4, pp. 261-269, 2005.

[30] K. A. Seifert, W. E. Hamilton, C. Breuil, and M. Best, "Evaluation of Bacillus subtilis $\mathrm{C} 186$ as a potential biological control of sapstain and mould on unseasoned lumber," Canadian Journal of Microbiology, vol. 33, no. 12, pp. 1102-1107, 1987.

[31] K. A. Seifert, C. Breuil, L. Rossignol, M. Best, and J. N. Saddler, "Screening for microorganisms with the potential for biological control of sapstain on unseasoned lumber," Material und Organismen, vol. 23, pp. 81-95, 1988.

[32] T. Singh and C. Chittenden, "In-vitro antifungal activity of chilli extracts in combination with Lactobacillus caseiagainst common sapstain fungi," International Biodeterioration and Biodegradation, vol. 62, no. 4, pp. 364-367, 2008.

[33] I. E. Cota, R. Troncoso-Rojas, R. Sotelo-Mundo, A. SánchezEstrada, and M. E. Tiznado-Hernández, "Chitinase and $\beta$ 1,3-glucanase enzymatic activities in response to infection by Alternaria alternata evaluated in two stages of development in different tomato fruit varieties," Scientia Horticulturae, vol. 112, no. 1, pp. 42-50, 2007.

[34] X. Z. Dong and M. Y. Cai, Manual of Systematic and Determinative Bacteriology, Science Press, Beijing, China, 2001.

[35] R. E. Buchanan and N. E. Gibbons, Bergey's Manual of Determinative Bacteriology, Williams \& Wilkins, Baltimore, Md, USA, 9th edition, 1994.

[36] R. Devereux and S. G. Willis, Molecular Microbial Ecology Manual, Kluwer Academic Publishers, Dordrecht, The Netherlands, 1995.

[37] R. Sipos, A. J. Székely, M. Palatinszky, S. Révész, K. Márialigeti, and M. Nikolausz, "Effect of primer mismatch, annealing temperature and PCR cycle number on 16S rRNA gene-targetting bacterial community analysis," FEMS Microbiology Ecology, vol. 60, no. 2, pp. 341-350, 2007.

[38] S. Schroeder, S. H. Kim, W. T. Cheung, K. Sterflinger, and C. Breuil, "Phylogenetic relationship of Ophiostoma piliferum to other sapstain fungi based on the nuclear rRNA gene," FEMS Microbiology Letters, vol. 195, no. 2, pp. 163-167, 2001.

[39] L. Cede, S. Mohali, and E. Palacios-Pru, "Ultrastructure of lasiodiplodia theobromae causal agent of caribbean pine blue stain in Venezuela," Interciencia, vol. 21, no. 5, pp. 264-271, 1996.

[40] N. Osman, Efficacy of fungicide against Fusarium solani Sacc. and Lasiodiplodia theobromae Pat. fungi on four clones of heveawood [M.S. thesis], Universiti Putra Malaysia, Selangor, Malaysia, 2001.

[41] K. L. Sajitha and E. J. M. Florence, "Effects of streptomyces sp. on growth of rubberwood sapstain fungus Lasiodiplodia theobromae," Journal of Tropical Forest Science, vol. 25, no. 3, pp. 393-399, 2013. 
[42] T. C. Harrington and M. J. Wingfield, "The Ceratocystis species on conifers," Canadian Journal of Botany, vol. 76, no. 8, pp. 1446-1457, 1998.

[43] F. Roll-Hansen and H. Roll-Hansen, "Microorganisms which invade Picea abies in seasonal stem wounds," European Journal of Forest Pathology, vol. 10, no. 6, pp. 321-339, 1980.

[44] S. H. Kim, A. Han, J. Kronstad, and C. Breuil, "Differentiation of sapstain fungi by restriction fragment length polymorphism patterns in nuclear small subunit ribosomal DNA," FEMS Microbiology Letters, vol. 177, no. 1, pp. 151-157, 1999.

[45] J. J. Kim, J. B. Ra, H. J. Kim, and G. H. Kim, "Sapstain and mold control on radiata pine lumber: laboratory and field tests of selected fungicides," Mycobiology, vol. 30, no. 1, pp. 37-40, 2002.

[46] S. S. Feio, A. Barbosa, M. Cabrita et al., "Antifungal activity of Bacillus subtilis 355 against wood-surface contaminant fungi," Journal of Industrial Microbiology and Biotechnology, vol. 31, no. 5, pp. 199-203, 2004.

[47] M. Fridlender, J. Inbar, and I. Chet, "Biological control of soilborne plant pathogens by a $\beta-1,3$ glucanase-producing Pseudomonas cepacia," Soil Biology and Biochemistry, vol. 25, no. 9, pp. 1211-1221, 1993.

[48] H. J. Potgieter and M. Alexander, "Susceptibility and resistance of several fungi to microbial lysis," Journal of Bacteriology, vol. 91, no. 4, pp. 1526-1532, 1966.

[49] H. G. Mena-Violante and V. Olalde-Portugal, "Alteration of tomato fruit quality by root inoculation with plant growthpromoting rhizobacteria (PGPR): Bacillus subtilis BEB-13bs," Scientia Horticulturae, vol. 113, no. 1, pp. 103-106, 2007.

[50] E. Jongedijk, H. Tigelaar, J. S. C. van Roekel et al., "Synergistic activity of chitinases and $\beta$-1,3-glucanases enhances fungal resistance in transgenic tomato plants," Euphytica, vol. 85, no. 1-3, pp. 173-180, 1995. 


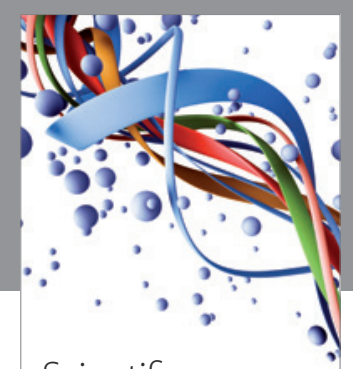

Scientifica
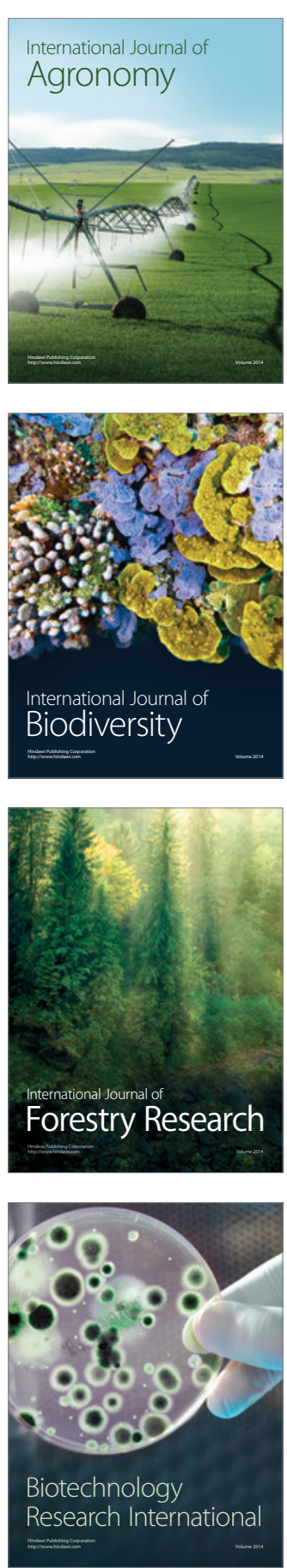
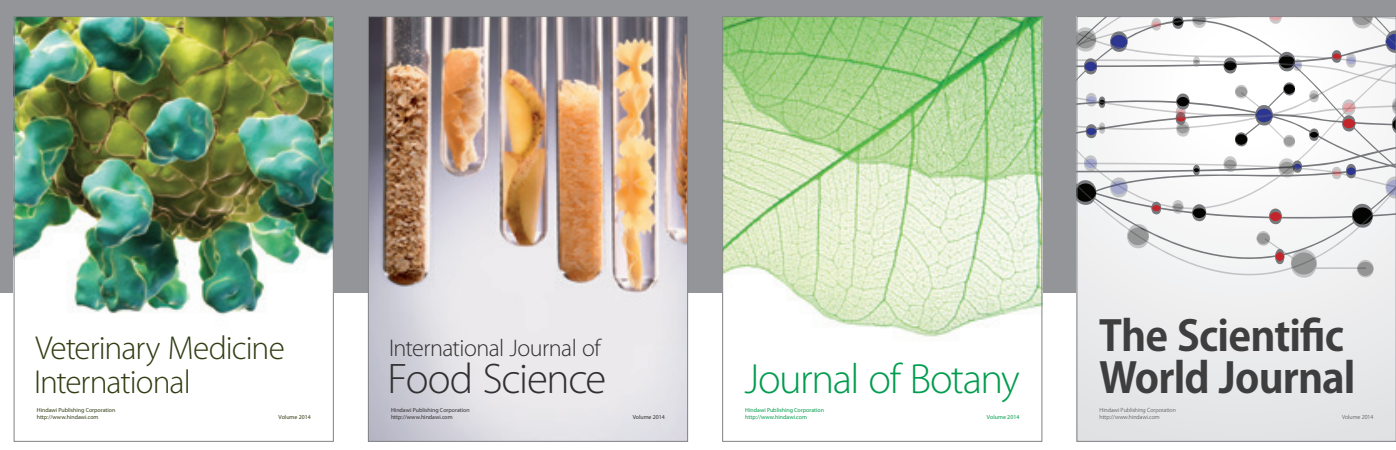

The Scientific World Journal
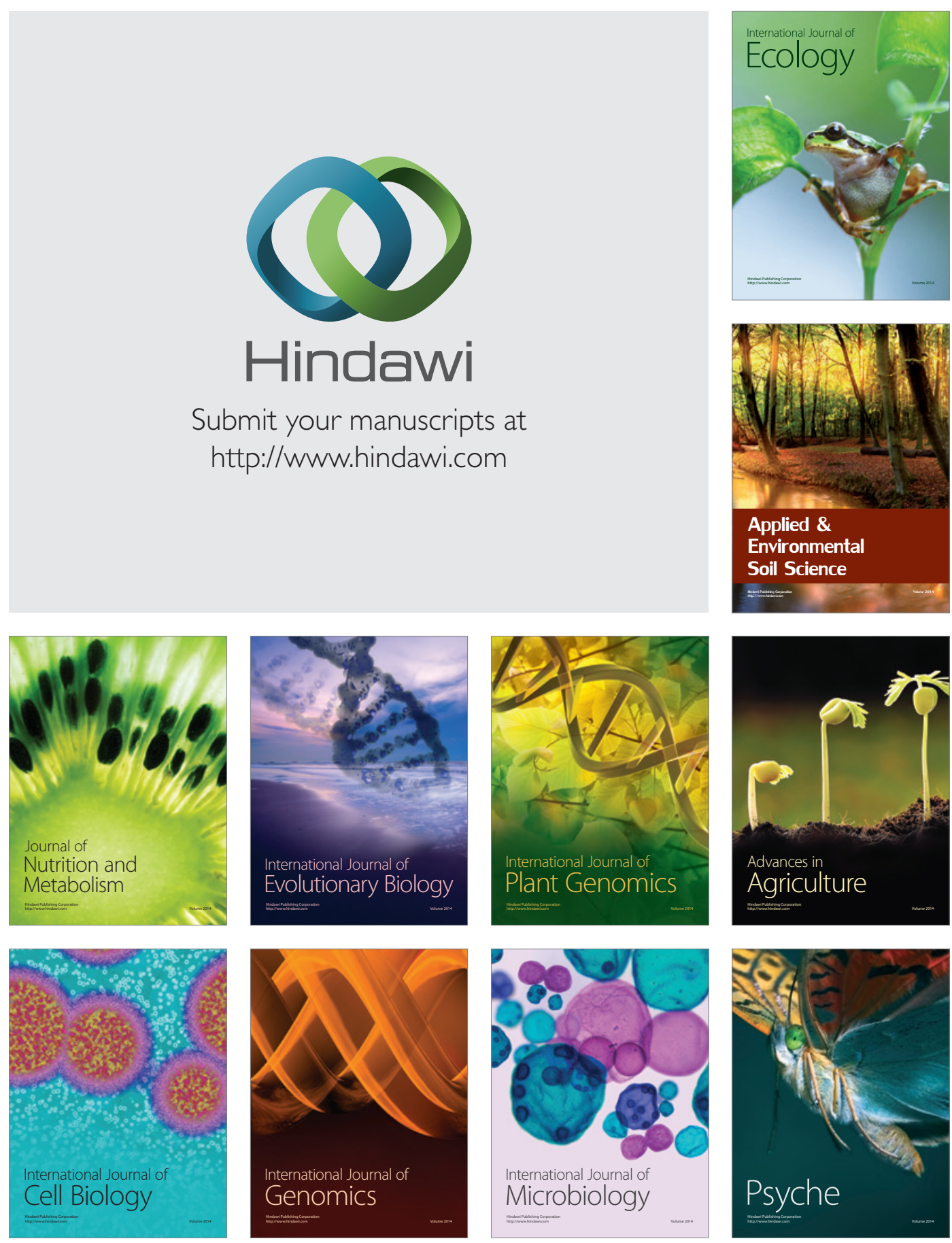